\title{
Industrial Symbiosis through the Use of Biosolids as Fertilizer in Romanian Agriculture
}

\author{
Lucian-Ionel Cioca ${ }^{1,2,3}{ }^{\mathbb{D}}$, Alina-Oana Ciomos ${ }^{3}$, Daiana Șeitoar ${ }^{3, *}$, Roxana Maria Druță ${ }^{3} \mathbb{D}$ and \\ Geanina Maria David ${ }^{3}$ \\ 1 Department of Industrial Engineering and Management, Faculty of Engineering, Lucian Blaga University \\ of Sibiu, 550024 Sibiu, Romania; lucian.cioca@ulbsibiu.ro \\ 2 Academy of Romanian Scientists, 010071 Bucharest, Romania \\ 3 Institute for Research in Circular Economy and Environment "Ernest Lupan" (IRCEM), 400609 Cluj-Napoca, \\ Romania; alina.ciomos@ircem.ro (A.-O.C.); roxana.druta@ircem.ro (R.M.D.); \\ geanina.david@ircem.ro (G.M.D.) \\ * Correspondence: daiana.seitoar@ircem.ro; Tel.: +40-740-265-737
}

Citation: Cioca, L.-I.; Ciomoş, A.-O.; Șeitoar, D.; Druță, R.M.; David, G.M. Industrial Symbiosis through the Use of Biosolids as Fertilizer in Romanian Agriculture. Recycling 2021, 6, 59. https://doi.org/10.3390/ recycling6030059

Academic Editors: Elena Rada, Elena Magaril and Giovanni De Feo

Received: 1 July 2021

Accepted: 2 September 2021

Published: 7 September 2021

Publisher's Note: MDPI stays neutral with regard to jurisdictional claims in published maps and institutional affiliations.

Copyright: () 2021 by the authors. Licensee MDPI, Basel, Switzerland. This article is an open access article distributed under the terms and conditions of the Creative Commons Attribution (CC BY) license (https:// creativecommons.org/licenses/by/ $4.0 /)$.

\begin{abstract}
Biosolids' use in agriculture is an example of industrial symbiosis. The application of biosolids (BS) in agriculture is considered one of the most sustainable sewage sludge (SS) management options, but the quality of biosolids has to meet certain requirements regarding the characteristics of the sludge, those of the land and of the type of crop. Web of Science database has been used to search for the relevant literature. The review of studies undertaken in order to determine the economic effects of the use of biosolids in agriculture shows, in the majority, an increase in crop yield and the reduction in costs, due to the reduction in the requirements for the application of chemical or synthetic fertilizers. If the entire sewage sludge production in Romania for 2019 had been used as fertilizer, the estimated cost reduction for farmers would have been almost 3 million Euros-considering the 230.59 thousand tons of dry matter produced in 2019. The estimated savings for 2019 of the sewage and water utilities, if the sewage sludge had been used in agriculture instead of depositing it at the landfill, would have been about 3.9 million Euros. However, the limits of the symbiosis are due to the size of the farms, the type of plants cultivated, $\mathrm{pH}$, slope inclination, heavy metal content and social acceptance. It is impossible to use all the sewage sludge in agriculture, but these figures are a good estimation of the economic effects.
\end{abstract}

Keywords: fertilizer; biosolids (BS); industrial symbiosis (IS); Romania; sewage sludge (SS); crop yield

\section{Introduction \\ 1.1. Industrial Symbiosis}

Industrial symbiosis is a subdiscipline of a more general scientific field, the industrial ecology. The industrial ecology started being developed in the late 1980s, with its first definition being agreed, by the scientific community, to be in the manuscript "Strategies for Manufacturing" from 1989, written by Frosch and Gallopoulos in Scientific American, where they state that "the traditional model of industry activity ... should be transformed into a more integrated model: an industrial ecosystem. In such a system, the consumption of energy and materials is optimized, waste generation is minimized, and the effluents of one process ... serve as the raw material for another. The industrial ecosystem would function as an analogue of biological ecosystems" [1].

In 1997, in the context of industrial ecology, Erkman proposed us to "understand how the industrial system works, how it is regulated and its interaction with the biosphere; then, on the basis of what we know about ecosystems, to determine how it could be restructured to make it compatible with the way natural ecosystems function" [2].

In 2004, Chertow defined the industrial symbiosis as consisting of "place-based exchanges among different entities that yield a collective benefit greater than the sum of 
individual benefits that could be achieved by acting alone. Such collaboration can also foster social values among the participants, which can extend to surrounding neighborhoods" [3].

Allenby (1999) called industrial ecology the science of sustainability [4]. The definition given by Allenby for industrial ecology refers to "a system-based, multidisciplinary discourse that seeks to understand emergent behavior of complex integrated human/natural systems." [5] According to his definition, industrial ecology has a system approach and involves many scientific fields, from the technical, economic and ecological ones to sociological and philosophical ones [6].

According to $\mathrm{Li}$, the core focus of the industrial ecology consists in the design and transformation of industrial systems in nearly closed-loop industrial ecosystems. Industrial ecology comprises four interrelated fields: industrial ecosystems, industrial symbiosis, industrial metabolism and environmental legislation and regulations [7].

As a general definition, industrial symbiosis focuses on resource optimization among companies in the vicinity [8]. Ancillary services, such as transportation, landscaping and waste collection, can be shared among companies, as much as the management of the utilities, such as energy, water or wastewater treatment [9].

The most popular example of industrial symbiosis with a circular approach is set among several different industries in the small town of Kalundborg, Denmark and refers to their unique partnership in sharing groundwater, surface water, wastewater, steam, sludge, gas, sulfur, fuel etc. [10].

In the study of the European Commission, "Analysis of certain waste streams and the potential of industrial symbiosis to promote waste as a resource for EU industry", published in 2015, at least three types of industrial symbiosis (IS) processes have been defined [11]:

(i). IS type 1, in which product residues and waste are reused within the same companies. This type of industrial symbiosis requires adaptation of processes and construction of transfer systems for the reuse and use in cascade of product residues. This type of industrial symbiosis is synonymous with environmental management or cleaner production.

(ii). IS type 2, in which product residues and waste are reused by another company. This type of industrial symbiosis requires development of partnerships between companies at local or regional level.

(iii). IS type 3, in which product residues and waste products are sold on the market. This type of industrial symbiosis requires by-products, waste treatment and handling companies which provide materials to other people and companies to be used as input in their production processes.

If one company's waste stream is raw material for another company (IS2 and IS3), the industrial symbiosis represents an ideal model of circular economy [11].

The industrial symbiosis is one way of increasing the resources' use effectiveness in the context of sustainable development. It has been observed that the countries with the higher quality of life are those countries that are more efficient in managing their resources, proving themselves to be more innovative, productive at a lower cost and having a lower impact on the environment [12].

\subsection{Production of Sewage Sludge (SS)}

The sewage sludge is a byproduct obtained after the treatment process of wastewater $[13,14]$. After undergoing treatments (pre-treatment, biological and other treatments), sedimentation (primary and secondary) and recirculation in the wastewater line, the sludge further undergoes changes in the sludge line (including primary sludge, secondary sludge and mixed sludge). The final result after dewatering and stabilization processes consists of biosolids which can be further used in agriculture and other reuse, can be incinerated or reach landfills. The road of the sewage sludge is represented in Figure 1. 


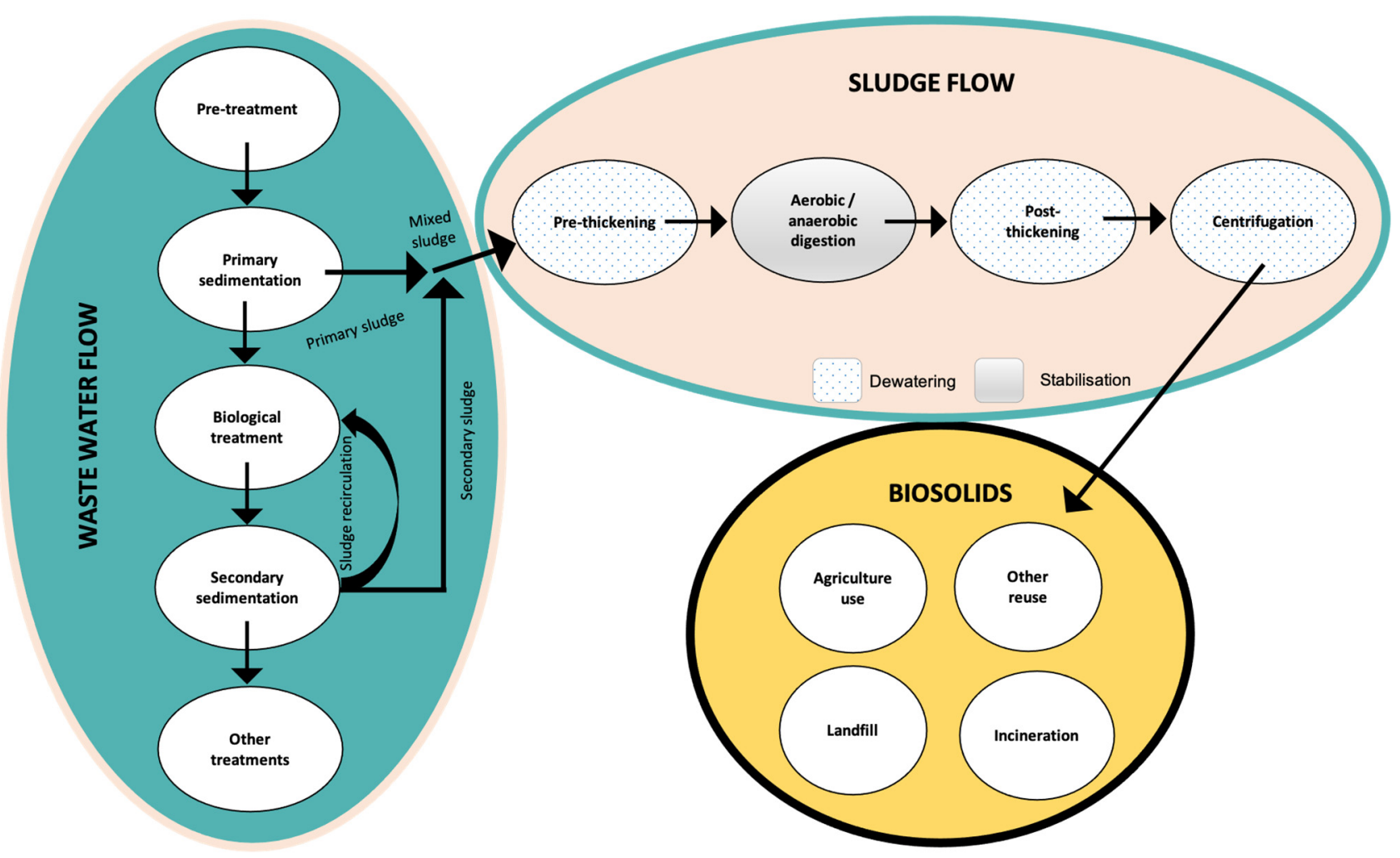

Figure 1. Scheme example of a conventional WWTP with a sludge line. Adapted from [15].

In Romania, the entire territory has been declared as a "sensitive area to nutrients" due to comprising the Danube's watershed and the Black Sea basin within the country's borders. As an environmental protection measure, agglomerations of less than 10,000 inhabitants require having infrastructure for secondary treatment (biological stage) in their urban wastewater treatment processes, whereas for agglomerations with more than 10,000 inhabitants, infrastructure for tertiary treatment-especially in terms of removing the nutrients (total nitrogen and total phosphorus) is required [16,17].

Regarding the sewerage sector in Romania:

- At the country level, in 2008, 9,237,821 inhabitants benefited from the sewerage service, representing $43 \%$ of the population of the country and in 2019 , a number of $10,514,924$ inhabitants had their households connected to the sewerage systems, representing $54.2 \%$ of the resident population of Romania, with 221,883 persons more than in 2018 [18].

- In terms of wastewater treatment, at country level, the population connected to the sewage systems provided with wastewater treatment plants was of 10,264,302 persons in 2019 , representing $52.9 \%$ of the country's resident population, with 229,014 more people than in 2018, in comparison to $9,237,821$ inhabitants in 2008 , representing $43 \%$ of the population of Romania [18].

The evolution of the degree of connection of the population to systems of collection and treatment of the wastewater indicates a constant increase in the number of the population benefiting from services of sewerage, the consequence of the extension and of the construction of the related infrastructure. It is noted that, in the last period, the proportion of tertiary wastewater treatment systems has increased in particular [19]. Modernization and construction of new wastewater treatment plants are also responsible for an increase in the sewage sludge quantity [20]. Moreover, the expenses related to sludge management amount to $50 \%$ of the wastewater treatment plant operating expenses [21,22]. 


\subsection{Biosolids Application in Agriculture}

The use of sewage sludge as biosolids (BS) in agriculture is included in the second type of industrial symbiosis: product residues/waste reused by another company. As we stated above, this type of industrial symbiosis places a special emphasis on developing partnerships between water operators and farmers. The agricultural outlet is considered, in both the scientific community and the practitioners' one, to be the best practicable environmental option for sewage sludge disposal $[20,22,23]$, taking into consideration a series of criteria such as practicability, affordability, sustainability and acceptability [23]. Still, the appliance of sludge in agriculture is conditioned by retailer and social acceptance and can be risky from the environmental and health points of view $[20,23]$. The sewage sludge comprises both organic and inorganic materials, a large concentration of plant nutrients as toxic organic chemicals and pathogens $[13,17]$. That is why precautions should be taken into consideration when assessing what is practicable, affordable, desirable and necessary [23].

In order to minimize environmental and health repercussions, the sewage sludge needs proper treatment and processing $[13,17]$. When properly treated and processed, sewage sludge becomes biosolids [24,25].

Biosolids can be used as fertilizers for improving and maintaining productive soils and stimulating plant growth [24]. The first step in the sewage sludge treatment plan is thickening. The second step is a biological process in which the organic solids present in the sludge are decomposed into stable substances and it is called digestion. The last step before final disposal is dewatering and follows the retrieving of useful gases and other byproducts [13].

In Romania, $99.5 \%$ of the farms are individual farms, amounting to $55 \%$ of the total agricultural area of Romania. The average size of a farm is 1.8 ha, which makes it impractical for water utilities to supply and apply sludge. In contrast, commercial farms represent $0.5 \%$ of all farms, but they own $45 \%$ of agricultural area, with an average total area of 282 hectares, which makes them fit for the application of BS. Restrictions on the use of biosolids on different crops have a significant impact on the proportions of land suitable for sludge application. At a national level, $59 \%$ of the farms' land grow crops are suitable for sludge application, but this proportion varies considerably throughout Romania (from $20 \%$ in the central region and up to $80 \%$ in the southern region) due to the different agro-ecological climate [22].

With regard to the availability of the land that is suitable for biosolids application, there are a lot of factors to take into consideration. The most important ones, when analyzing soil suitability, are:

- The application of biosolids to crops with an area larger than 20 ha (especially those from agricultural units with legal personality) is, from an operational and administrative points of view, simpler and easier to perform than applying them on many small lands (especially those of individual farmers) [22];

- Care is required regarding the placement of BS in or near areas with protected or vulnerable water sources [22];

- The slope of the land, since the risk of leakage to surface water sources and mechanical application problems increases with the increase in the slope. Biosolids application on slopes less than $15 \%$ is acceptable, assuming there are no other limiting factors or risks [26];

- The soil texture-avoid too strong or too loose soil [26];

- The soil chemical composition- $\mathrm{pH}$ and heavy metal concentrations are limiting factors according to Ministry Order (MO) 344/2004 of the Romanian Government. Biosolids can be applied on agricultural land with $\mathrm{pH} \geq 6.5$ (constraint which is much stricter than in other countries) [26];

- The type of crop-MO 344/2004 prohibits the use of biosolids in vegetable and fruit crops growing in shrubs, vines, pastures and restricts the use of sludge in orchards 
(application no less than 10 months before the first harvest). Biosolids can be applied to all other crops [26];

- Biosolids' quality should be compliant with the requirements of MO 344/2004;

- The nutritional needs of plants must be taken into account [26];

- Not to compromise the quality of soils and surface waters [26].

The responsibilities of BS producers are the following ones:

- To treat sludge properly, in order to significantly reduce fermentation properties, the presence of pathogens and the values of heavy metal concentrations in the sludge [27];

- To produce a safe, good quality sludge, which does not negatively impact the soil fertility and which assures environmental safety and human health integrity [27];

- To identify the users of the sludge and the agricultural lands that meet the necessary conditions for the application of the sludge, with regard to the type and quality of the soils and the type and rotation of agricultural crops [26,27];

- To ensure the transportation and the spreading of sludge [27];

- To provide control and monitoring of soils on which sludge has been applied [27];

- To notify the territorial environmental authority and the bs users about the possible pollutants existing in the sludge [26];

- To contact the bs user and to evaluate the possibilities of bs use [26].

The responsibilities of the BS users are [27]:

- To inform the competent authorities and the sludge producer (water supply and sewerage utility) about the rotation of agricultural crops;

- To ensure that the biosolids are integrated into the soil on the same day as the biosolids are spread;

- To inform the sludge producer if they change their mind about using the biosolids before transporting it.

\section{Materials and Methods}

The proposed review article aims to verify the hypothesis according to which IS2 and IS3 are beneficial to agricultural yield and, if so, which are the limits of this type of co-operation among sectors. In the following sections, details about methods of identifying and analyzing published articles in the field are being provided.

Respecting the review process stages described by Kitchenham in 2004 [28] described below, we undertook a systematic review in accordance with a predefined search strategy, as follows:

- Step 1. Planning the review, with two stages: identification of the need for a review and the development of a review protocol;

- Step 2. Conducting the review, with five stages: identification of research, selection of primary studies, studies' quality assessment, data extraction and monitoring and data synthesis;

- $\quad$ Step 3. Reporting the review, a single stage step.

Within step 2, we proposed a protocol for the relevant literature identification, described in Table 1. 
Table 1. Protocol for the literature identification.

\section{Criteria}

Reasons

(1) Identification of the publications in the fields of "biosolids", "agriculture" and "fertilizer"

(2) Publications as a full-length journal article or review

(3) Exclusion of publications with other aims than the calculation of economic yield of biosolids' application in agriculture

(4) Publications underlining the economic effects of biosolids' application in agriculture
The proposed review article is supported by a comprehensive review of the world literature. Web of Science database has been used to search for the relevant literature. In order to find all relevant publications, the keywords used derived from the purpose statement and identified the concepts of interest, namely: "biosolids", "agriculture" and "fertilizer" The analysis has been conducted searching the keywords on the fields "Article title, Abstract, Keywords" and we got 118 results.

We excluded book reviews and conference proceedings papers. Only peer-review full papers published on international journals have been considered, meaning 33 articles. The search was conducted in March 2020.

Articles with the following properties:

- $\quad$ does not include biosolids (e.g., urine fertilizer instead of biosolids);

- $\quad$ is a review article;

- does not include crop yield, but only: pathogens, antibiotic resistance genes, impacts of BS on soil fungal communities, the concentration of trace elements in crops, pharmaceutical and personal care products in soils;

- $\quad$ improper crops (vegetables and fruit crops growing in shrubs, vines, pastures and restriction of use of sludge in orchards) or crops whose edible part is in direct contact with soil;

- not in English have not been taken in consideration.

8 full-length peer-reviewed articles written in English comprised experiments related to the economic effects of using biosolids as fertilizer on crops.

\section{Results}

\subsection{Fertilizing Properties of Biosolids}

The intense use of chemical fertilizers causes water contamination, loss of nutrients, and deterioration of soil. It is estimated that $30-50 \%$ of fertilizer nutrients are either leached to groundwater or volatilized to air [29].

For optimal agricultural benefits, biosolids must have both macro and micro-nutrients necessary for the healthy growth of plants $[25,27,30,31]$ such as regarding organic matter, nitrogen, phosphorus and potassium, to which sulfur, magnesium, calcium, manganese, zinc and copper are added [27]. Due to the high content of organic material, dry biosolids can improve clay soils and the structure of sandy soils [27].

Concerning the average nutrient concentration of the sewage sludge in Romania, we can affirm that it is typical, having the following values: $3.5 \% \mathrm{~N}, 1 \% \mathrm{P}$ and $0.2 \% \mathrm{~K}$. The organic matter content of $50 \%$ indicates that the sludge is generally stabilized and the maximum value of $80 \%$ is valid for raw sludge (non-stabilized). A maximum application rate of biosolids of $5 \mathrm{t}$ of dry substance/hectare is taken into account, based on the median concentration of nitrogen (3.6\% N dry substance) and the maximum addition of $170 \mathrm{~kg}$ $\mathrm{N} /$ ha per year allowed in areas vulnerable to nitrates [22].

The use of wastewater sludge in agriculture is increasing in Romania; the last value we have from the National Statistics Institute shows that about $19 \%$ of the sewerage sludge was used in agriculture in Romania in 2019 [18].

In Table 2, recent experiments regarding the economic effects of biosolids' application in agriculture are summarized. 
Table 2. Experimental investigations on biosolids' (BS) use in agriculture and their effect on crop yield.

\begin{tabular}{|c|c|c|c|c|c|c|c|c|c|c|c|c|}
\hline Ord. No. & BS & $\begin{array}{l}\text { Type of } \\
\text { Fertilizer }\end{array}$ & Crop Type & $\mathrm{P}, \mathrm{N}$ & $\begin{array}{l}\text { Organic } \\
\text { Matter }\end{array}$ & Soil pH & $\begin{array}{l}\text { Heavy } \\
\text { Metals in } \\
\text { Crops }\end{array}$ & $\begin{array}{l}\text { Pathogens in } \\
\text { Crop }\end{array}$ & Crop Yield & $\begin{array}{l}\text { Retention of } \\
\text { Carbon }\end{array}$ & $\begin{array}{l}\text { Retention of } \\
\text { Water }\end{array}$ & Reference \\
\hline 1 & $\begin{array}{l}\text { Lime stabilized } \\
\text { biosolids; } \\
\text { Composted } \\
\text { biosolids; Liquid } \\
\text { Mesophilic } \\
\text { Anaerobic } \\
\text { Digestion (MAD) } \\
\text { biosolids; } \\
\text { Thermally dried } \\
\text { MAD; Thermally } \\
\text { Hydrolyzed } \\
\text { MAD; Dewatered } \\
\text { MAD; } \\
\text { Thermally-dried } \\
\text { raw biosolids }\end{array}$ & $\begin{array}{l}\text { Mineral } \\
\text { fertilizers }\end{array}$ & wheat & $\begin{array}{l}\text { The highest } \\
\text { nitrogen } \\
\text { contents } \\
\text { were found } \\
\text { in dewatered } \\
\text { MAD } \\
\text { biosolids } \\
\text { while } \\
\text { phosphorous } \\
\text { contents } \\
\text { were } \\
\text { maximum in } \\
\text { liquid MAD } \\
\text { biosolids. }\end{array}$ & & $\begin{array}{l}\text { Alkaline, } \mathrm{pH} \\
\text { ranged from } \\
7.4 \text { to } 8.9\end{array}$ & & & Increased & . & & [14] \\
\hline 2 & $\begin{array}{l}\text { SS combined } \\
\text { with three } \\
\text { different } \\
\text { amounts of } \\
\text { mineral fertilizer, } \\
\text { no, half or full } \\
\text { dose of N; } \mathrm{P} \text { and } \\
\mathrm{K} \text { are added at } \\
\text { both half and full } \\
\mathrm{N} \text { input }\end{array}$ & $\begin{array}{l}\text { Not } \\
\text { amended, } \\
\text { mineral } \\
\text { fertilizer }\end{array}$ & $\begin{array}{l}\text { Wheat, sugar } \\
\text { beet, Spring } \\
\text { barley, oats }\end{array}$ & $\begin{array}{l}\text { Low fertilizer } \\
\text { value of } \mathrm{P} \\
\text { and } \mathrm{N}\end{array}$ & & & Within limits & Within limits & $\begin{array}{l}\text { Increased } \\
\text { crop yield, } \\
\text { mineral } \\
\text { fertilizer had } \\
\text { a much } \\
\text { greater } \\
\text { impact on } \\
\text { yield than BS }\end{array}$ & $\begin{array}{l}\text { Higher soil } \\
\text { carbon con- } \\
\text { centration, } \\
\text { lower soil } \\
\text { bulk density }\end{array}$ & & [32] \\
\hline 3 & Sewage sludge & $\begin{array}{l}\text { Mineral } \\
\text { fertilizer }\end{array}$ & $\begin{array}{l}\text { Maize, } \\
\text { sunflower, } \\
\text { crotalaria }\end{array}$ & $\begin{array}{l}\text { Efficient in } \\
\text { completely } \\
\text { replacing P } \\
\text { fertilization, } \\
\text { partially } \\
\text { replace N } \\
\text { fertilization }\end{array}$ & $\begin{array}{l}\text { No increase } \\
\text { of organic } \\
\text { matter }\end{array}$ & & & & Increased & & & [33] \\
\hline 4 & Air dried SS & $\begin{array}{l}\text { Not } \\
\text { amended }\end{array}$ & Broad bean & & Increased & Decreased & Within limits & & Increased & & Increased & [34] \\
\hline 5 & Air dried SS & $\begin{array}{l}\text { Conventional } \\
\text { fertilizer, } \\
\text { slow-release } \\
\text { fertilizer }\end{array}$ & $\begin{array}{l}\text { Ornamental } \\
\text { flowers: } \\
\text { dianthus, } \\
\text { kale, or } \\
\text { petunia }\end{array}$ & $\begin{array}{l}\text { BS added } \\
\text { significant } \\
\text { amounts of } \mathrm{P} \\
\text { to the } \\
\text { system, } \mathrm{N} \\
\text { source }\end{array}$ & $\begin{array}{l}\text { Increasing } \\
\text { higher than } \\
\text { with } \\
\text { conventional } \\
\text { fertilizer }\end{array}$ & Decreased & $\begin{array}{l}\text { Higher levels } \\
\text { of copper, } \\
\text { manganese, } \\
\text { magnesium, } \\
\text { and zinc than } \\
\text { synthetic } \\
\text { fertilizers }\end{array}$ & $\begin{array}{l}\text { None } \\
\text { detected }\end{array}$ & $\begin{array}{l}\text { Same as } \\
\text { conventional } \\
\text { fertilizers }\end{array}$ & & $\begin{array}{l}\text { improve } \\
\text { water- } \\
\text { holding } \\
\text { capacity }\end{array}$ & [35] \\
\hline
\end{tabular}


Table 2. Cont.

\begin{tabular}{|c|c|c|c|c|c|c|c|c|c|c|c|c|}
\hline Ord. No. & BS & $\begin{array}{l}\text { Type of } \\
\text { Fertilizer }\end{array}$ & Crop Type & $\mathrm{P}, \mathrm{N}$ & $\begin{array}{l}\text { Organic } \\
\text { Matter }\end{array}$ & Soil pH & $\begin{array}{l}\text { Heavy } \\
\text { Metals in } \\
\text { Crops }\end{array}$ & $\begin{array}{l}\text { Pathogens in } \\
\text { Crop }\end{array}$ & Crop Yield & $\begin{array}{l}\text { Retention of } \\
\text { Carbon }\end{array}$ & $\begin{array}{l}\text { Retention of } \\
\text { Water }\end{array}$ & Reference \\
\hline 6 & $\begin{array}{l}\text { Secondary } \\
\text { treatment SS } \\
\text { with, biological } \\
\text { anaerobic } \\
\text { stabilization, } \\
\text { secondary } \\
\text { treatment SS, } \\
\text { primary } \\
\text { treatment SS }\end{array}$ & $\begin{array}{l}\text { Not } \\
\text { amended }\end{array}$ & $\begin{array}{l}\text { Sugarcane, } \\
\text { banana, } \\
\text { coffee, } \\
\text { orange, green } \\
\text { coconut, } \\
\text { corn, } \\
\text { pineapple, } \\
\text { tomato }\end{array}$ & $\begin{array}{l}\text { High } \\
\text { contents of } \mathrm{P}, \\
\mathrm{N} \text { in BS; low } \\
\text { K content in } \\
\text { BS }\end{array}$ & $\begin{array}{l}\text { High content } \\
\text { in BS }\end{array}$ & & Within limits & Within limits & $\begin{array}{l}\text { Increased } \\
\text { productivity }\end{array}$ & $\begin{array}{l}\text { Increasing } \\
\text { soil carbon } \\
\text { stock }\end{array}$ & & [36] \\
\hline 7 & $\begin{array}{l}\text { Dewatered BS } \\
\text { from primary } \\
\text { stabilization } \\
\text { ponds }\end{array}$ & $\begin{array}{l}\text { Without N, N } \\
\text { amended } \\
\text { fertilizer }\end{array}$ & Roses & $\begin{array}{l}\text { N higher } \\
\text { than in not } \\
\text { amended } \\
\text { studies }\end{array}$ & & & & & $\begin{array}{l}=\text { conventional } \\
\text { fertilizers }\end{array}$ & & & [37] \\
\hline 8 & $\begin{array}{l}\text { SS with or } \\
\text { without } \mathrm{N} \\
\text { and/or P } \\
\text { fertilizer }\end{array}$ & $\begin{array}{l}\text { NPK } \\
\text { fertilizer }\end{array}$ & Cane & & & & & & $\begin{array}{l}\text { Higher than } \\
\text { with the NPK } \\
\text { fertilizer } \\
\text { treatment }\end{array}$ & & & [38] \\
\hline
\end{tabular}


Starting from the studies indexed in Table 1, we can draw a series of conclusions regarding the crop yield, as follows:

- $\quad$ Biosolids proved successful in reducing the use of synthetic fertilizers in wheat crop used as fodder crop in Pakistan [14];

- After application of biosolids on maize crops on tropical soils for ten years, biosolids proved efficient in total replacement of $\mathrm{P}$ fertilization, macronutrients and partial replacement of $\mathrm{N}$ fertilization [33];

- Biosolids can successfully replace fertilizer in broad bean crops in Saudi Arabia [34];

- Larger cities can provide biosolids to smaller cities with larger agricultural areas [36];

- The application of sewage sludge in cane crops, enhanced or not with $\mathrm{N}$ and/or $P$ fertilizer, in Brazil, led to higher production of stack yield in comparison with application of NPK fertilizer alone [38], presented in Figure 2.

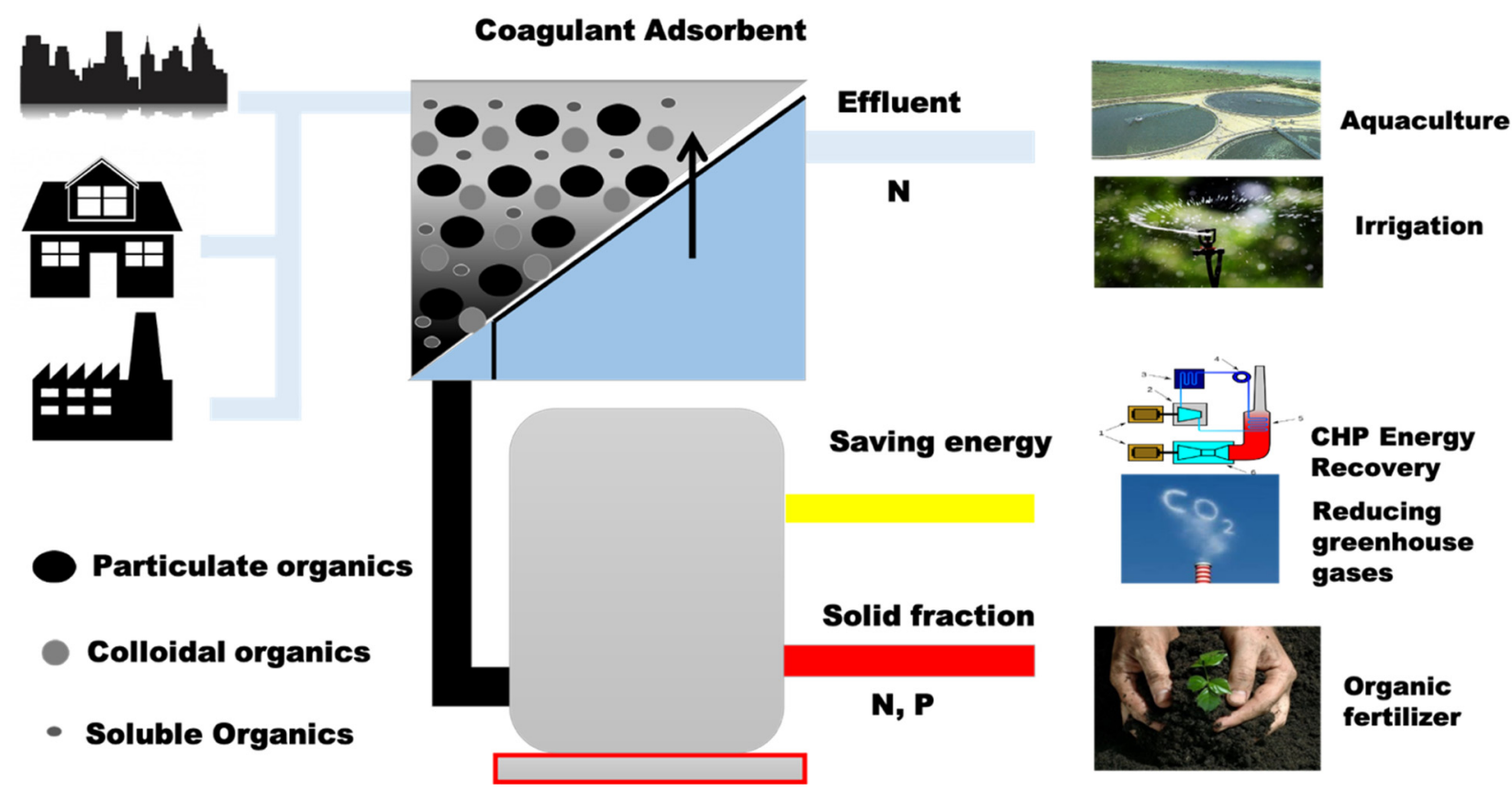

Figure 2. The outputs of treated wastewater, nutrients and sludge that are produced can be exploited to form an additional source of income.

At the same time, some authors obtained similar yield of crops when using BS to the use of conventional fertilizers:

- Soil properties are improved, and similar plant sizes are obtained when using BS on ornamental flowers in the USA as conventional and slow-release fertilizers [35];

- Biosolids successfully replaced mineral fertilizers when added on rose plants in an experiment made in Brazil [37].

Only one of the selected studies, "Soil fertility effects of repeated application of sewage sludge in two 30-year-old field experiments", undertaken by Borjesson and Katterer and published in 2018 [32] on wheat, sugar beet, spring barley and oats crops in Sweden concluded that, though biosolids seem to improve the soil fertility in terms of organic matter and structure, they are not very efficient in nutrient cycling.

Thus, in the following, we will present a proposal for the improvement for the use of an optimal quality of sludge in agriculture, in the figure below (Figure 3). 


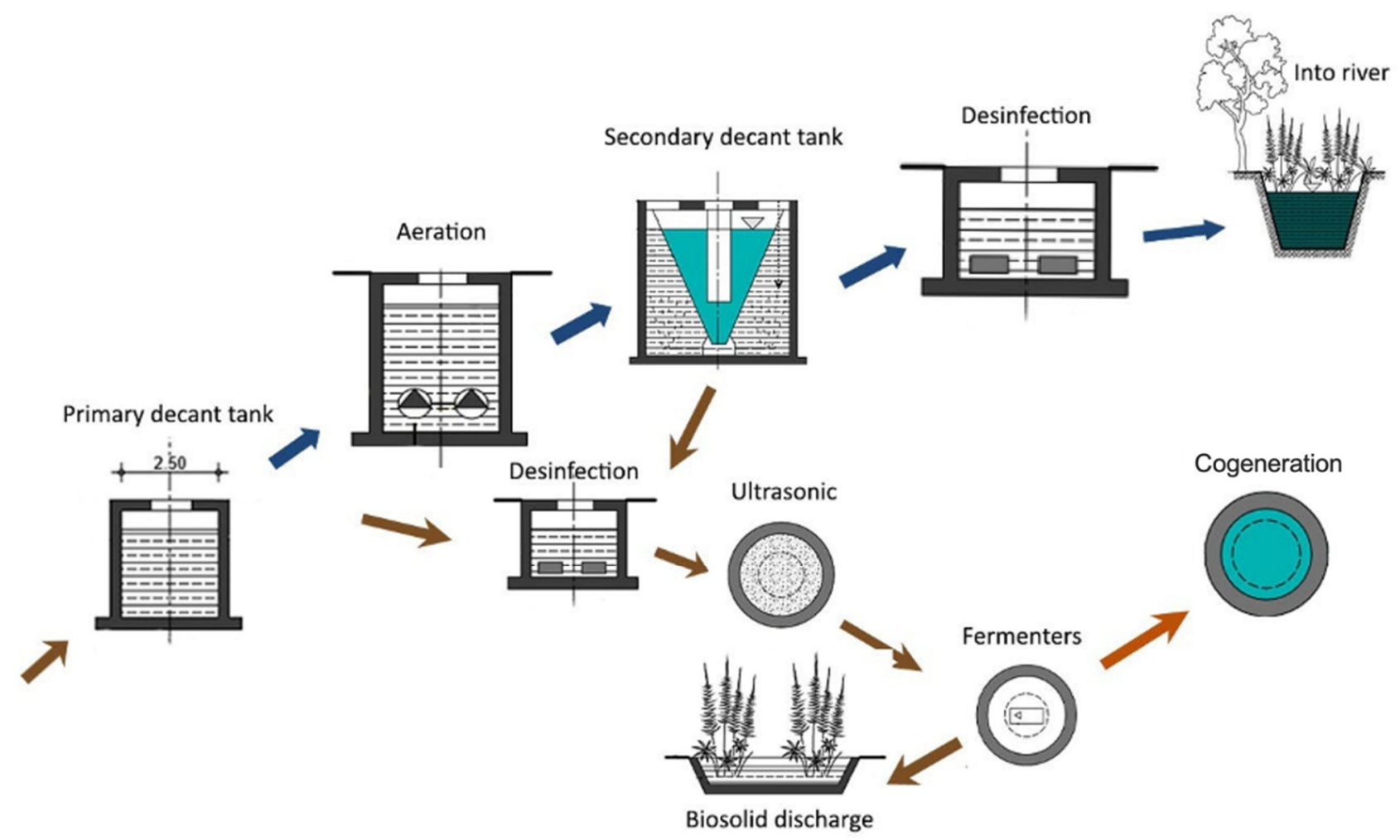

Figure 3. The improvement for the use of an optimal quality of sludge in agriculture in order to obtain biosolids.

Among the advantages of biosolids application in agriculture, we name the following [27]:

- Improvement of the physical, chemical and biological properties of the soils, through the contribution of stabilized organic substances;

- Increase in crop yields and reducing the use of agricultural fertilizers;

- Sustainable development of the environment, with benefits both for the sludge producer, as for the farmer;

- Improvement of the physical and organic properties of soils through the contribution of nutrients (nitrogen, phosphorus, sulfur), oligo-elements, organic compounds;

- $\quad$ Better water retention in soil;

- Improvement of microbial activity in soil;

- Low cost;

- Simple technology required.

\subsection{Measurements of the Economic Effects of Biosolids for Farmers}

Sewage sludge recycling in the agricultural area can represent considerable savings with chemical fertilizers, providing economic, environmental and social benefits, such as improved soil quality, productivity gains, less dependence on chemical fertilizers and lower production costs [36].

Bittencourt et al. [39] analyzed the economic effects of biosolids amendment on soils on more than 2200 hectares of agricultural areas, in Paraná State, from 2007 to 2010 and concluded that the 80 producers participating in the program saved an average of US $\$ 813.45 \mathrm{ha}^{-1}$ in fertilizers and other soil amendments.

According to UK regional water utility Severn Trent Water, ADAS (an independent agricultural and environmental consultancy company based in more cities in the UK) calculated the value of the biosolids to at least 12.59 Euros per ton in fertilizer replacement value in 2013 [40].

The evolution of sludge production in Romania from 2013 to 2019 and its use in agriculture is presented in Figure 4. 


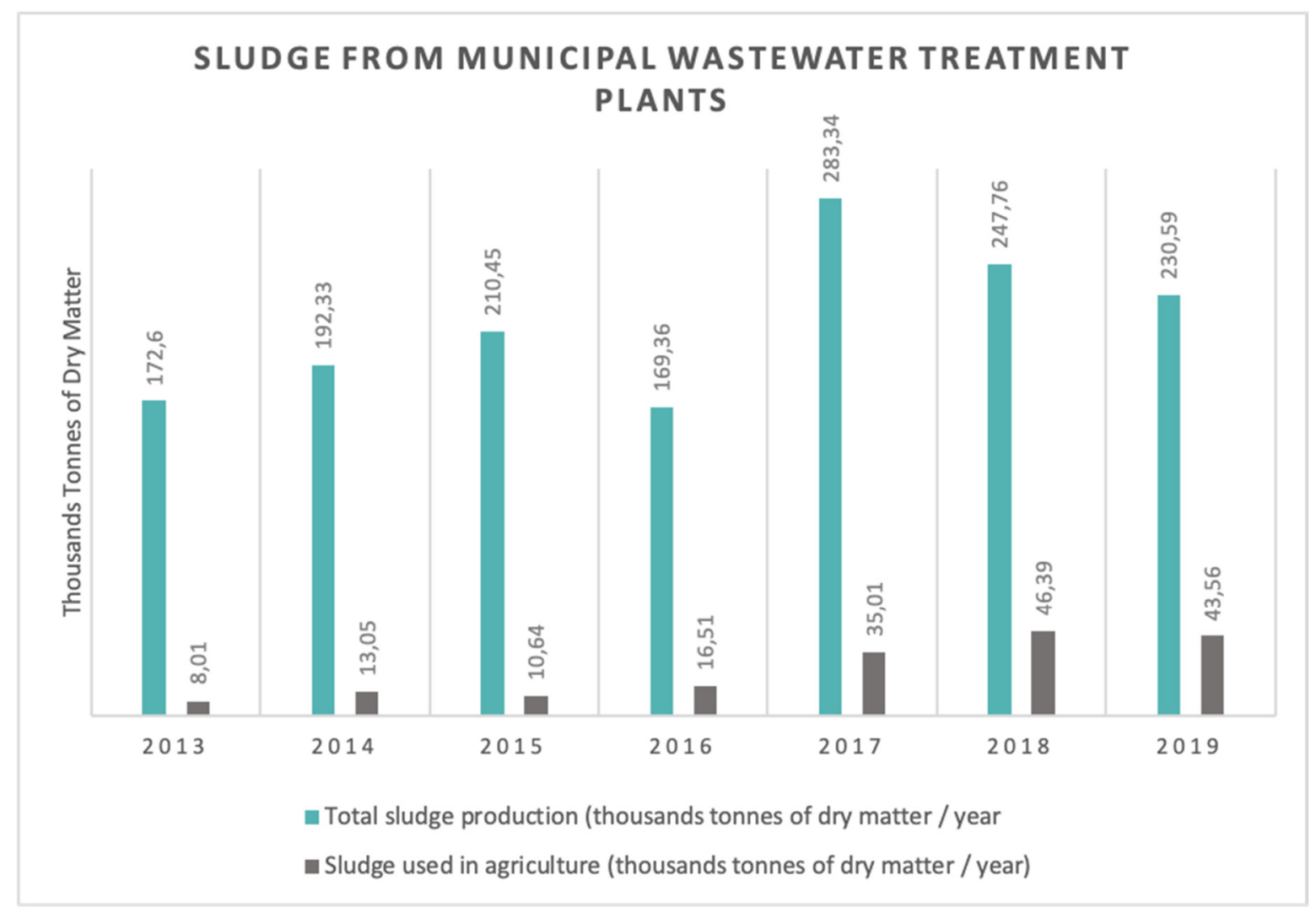

Figure 4. Production of biosolids and their use in agriculture in Romania in 2013-2019. Data source: National Statistics Institute [18].

Starting from the values provided by ADAS, in Romania, at the country level, if all the sludge had been used in agriculture or 247,76 thousand tons of dry matter in 2018 and 230.59 thousand tons of dry matter in 2019 , the fertilizer replacement value would have amounted to the equivalent of 3,084,504.60 Euros for 2018 only and 2,870,745.54 Euros for 2019. In other words, biosolids' use in agriculture is very profitable for farmers, leaving them with economies to support investment strategies.

\subsection{Measurements of the Economic Effects of Biosolids for Water Utilities}

The Law 384/2013 for the approval of the Government Emergency Ordinance 31/2013 for the amendment and completion of Government Emergency Ordinance 196/2005 on the Environment Fund [41] stipulates that, from the 1st of January 2017, the landfill waste disposal was charged with fees amounting to 17.8 Eur/ton in 2017 and to 25.7 Eur/t in 2018.

Emergency Ordinance 48/2017 for the amendment and supplementation of Government Emergency Ordinance 196/2005 on the Environment Fund [42] suspended the landfill waste disposal charge until January 2019. In this way, the waste to landfill disposal was no longer fined [43]. Starting from 1 January 2019, the charge for landfill waste disposal has been reintroduced, in a sum of 16.9 Eur/t in 2019 and 25.1 Eur/t in 2020.

If the landfill deposit would still have been taxed in 2018 and the total amount of sludge produced would have been stored in landfills, meaning 247.76 thousand tons of dry matter in 2018, this would cost the Romanian sewage utilities 6,367,432 Euros just for 2018 whereas the costs would be of 3,896,971 Euros for 2019. By avoiding costs for storing sludge in the landfill, the water and sewage utilities can maintain their operational costs at lower levels. 


\section{Discussion}

The analysis in this study investigated the economic effects of using biosolids in agriculture. Still, there are also other aspects of biosolids' use in agriculture that can constitute issues of concern.

The first of them is the control of the heavy metal content. The EU legislation establishes limit values for heavy metals in biosolids and also in soil [30]. According to Minister Order 344/2004, only treated sludge for which an application permit has been issued by the local environmental protection agency, based on the special agrochemical study prepared by the Office of Pedological and Agrochemical Studies (OSPA) and approved by the Directorate for Agriculture and Rural Development can be used in agriculture [26].

Sigua et al.'s research published in 2005, regarding the forage productivity and soil quality implications caused by repeated sewage sludge application in an experiment run in South Florida, USA, concluded that a cycle formed of three years of application of BS on crops, followed by at least two years without BS application, improve productivity in bahiagrass and keeps the level of nutrients, especially trace metals, within limits [44].

For proper utilization of sewage sludge, knowledge of the composition of the biosolids and of the crop receiving it is absolutely crucial in order that proper types and rates of biosolids are applied in an environmentally safe manner [44].

Another issue of concern is the presence of emerging trace organic contaminants (TrOCs), such as pharmaceuticals in sewage. At this point, little is still known about the variation in time and space of these contaminants, although the concentration of the compounds sold on medical prescription is easier to estimate than that of the over-thecounter drugs [45].

The literature suggests that some removal of TrOCs occurs during physical treatment (e.g., in thickening and dewatering stages) and in chemical treatment (e.g., during the conditioning stage) but a significant biodegradation and removal of these compounds takes place during sludge stabilization that involves aerobic conditions (e.g., air flotation, aerobic digestion, composting) more than those that involve anaerobic conditions. Advanced oxidation proved successful in removing TrOCs from biosolids, the greatest potential being demonstrated by ozonation and ultra-sonification [46].

Another issue of concern regards the presence of human pathogens, both in sewage sludge and biosolids, which can affect the environment and infect humans. Therefore, those pathogens should be reduced from the treated sewage and biosolids before their reuse in agriculture $[17,25]$.

Another topic, when considering the use of biosolids in agriculture, regards the Greenhouse gas emissions (GHG). Agriculture is an important GHG producer: in 2015, the agricultural sector produced about $10 \%$ of the EU's total GHG emissions for that year, meaning 426,473 kilotons of CO2 equivalent greenhouse gases. GHG from agricultural activities declined by $20 \%$ between 1990 and 2015 [47].

Data about the impact of biosolids application as a soil amendment on the carbon footprint of crop cultivation are still lacking. Glab and Sowinski focused on evaluating how sewage sludge and digestate application affect the Carbon footprint of sorghum production, compared with conventional fertilization management. The study concluded that the replacement of synthetic $\mathrm{N}$ fertilizers by alternative nutrient sources, such as sewage sludge and digestate resulted in lower GHG emissions and are a promising strategy for low carbon in agriculture [48].

And, finally, another issue related to biosolids' use in agriculture is social acceptance. Lindsay et al. suggest that there is a need for studies and educational programs that describe both the economic benefits, as the possible negative effects of crops amended with biosolids in order to support the formation of adequate positions from the residents [49]. At the moment in Romania, the industrial symbiosis is limited also by the size of farmsonly $0.5 \%$ of the farms are commercial enterprises that have a size suitable for using the sludge [22]. 
Because farmers and other stakeholders need stimulation and encouragement to perceive the benefits and safety of the BS, it should be mentioned that it is the responsibility of the regional water and sewerage services utilities to develop the "biosolids markets" through marketing programs, in order to assure the agricultural land needed to use the biosolids [22].

\section{Conclusions}

The studies reviewed by the article show that the application of BS enhanced soil fertility and crop yield in the amended soils was higher or equal, in general, than in the not amended crops. Still, the characteristics of the biosolids have to be controlled and monitored in order to minimize the potential impact on the environment and human health. At the same time, the characteristics of the land have to be monitored too, in order to receive the permit for biosolids' use in agriculture. Additionally, Romanian legislation prohibits the use of sludge in vegetable and fruit crops growing in shrubs, vines, pastures and restricts the use of sludge in orchards.

The use of sewage sludge is profitable also from the point of view of the savings it assumes. Thereby, at the country level, if all the sludge had been used in agriculture, the fertilizer replacement value would be worth the equivalent of about 3 million Euros for 2018 only and 2.9 million Euros for 2019. Moreover, exceptional savings can be achieved by water suppliers if they avoid discharge of sewage sludge at landfills. In this way, the water operators can maintain their operational costs at lower levels.

Author Contributions: Conceptualization, L.-I.C., D.S,. and A.-O.C.; design of analysis, L.-I.C., A.-O.C. and D.S.; methodology establishment, G.M.D., A.-O.C. and L.-I.C.; data collection and interpretation, A.-O.C.; writing-original draft preparation R.M.D. and A.-O.C.; writing-review, R.M.D., G.M.D., L.-I.C. and A.-O.C.; supervision, L.-I.C. and D.S. All authors have read and agreed to the published version of the manuscript.

Funding: This project is funded by the IRCEM on research and innovation programmer: Grant No. 473/IRCEM/20.11.2020.

Institutional Review Board Statement: Not Applicable.

Informed Consent Statement: Informed consent was obtained from all subjects involved in the study.

Data Availability Statement: Not Applicable.

Acknowledgments: This work received financial support of the Institute for Research in Circular Economy and Environment “Ernest Lupan”, Grant No. 473/IRCEM/20.11/2020.

Conflicts of Interest: The authors declare no conflict of interest.

\section{References}

1. Frosch, R.A.; Gallopoulos, N.E. Strategies for Manufacturing. Sci. Am. 1989, 261, 144-152. [CrossRef]

2. Erkman, S. Industrial Ecology: An Historical View. J. Clean. Prod. 1997, 5, 1-10. [CrossRef]

3. Chertow, M.R. Industrial symbiosis. Encycl. Energy 2004, 407-415. [CrossRef]

4. Allenby, B.R. Industrial Ecology: Policy Framework and Implementation; Prentice Hall: Englewood Cliffs, NJ, USA, 1999.

5. Allenby, B.R. The ontologies of industrial ecology? Prog. Ind. Ecol. Int. J. 2006, 3, 28-40. [CrossRef]

6. Clift, R.; Druckman, A. Taking Stock of Industrial Ecology; Springer: Guildford, UK, 2016; ISBN 978-3-319-20570-0.

7. Li, X. Industrial Ecology and Industrial Symbiosis for Environmental Sustainability. Definitions, Frameworks and Applications; Palgrave Macmillan: Sheffeld, UK, 2018; ISBN 978-3-319-67500-8.

8. Jacobsen, N.B. Industrial Symbiosis in Kalundborg, Denmark: A Quantitative Assessment of Economic and Environmental Aspects. J. Ind. Ecol. 2005, 10, 239-255. [CrossRef]

9. Ashton, W. Understanding the Organization of Industrial Ecosystems: A Social Network Approach. J. Ind. Ecol. 2008, 12, 34-51. [CrossRef]

10. Danielsson, M. Reuse Water between Businesses, Sustainable Sanitation and Water Management Toolbox. 2019. Available online: https: / /sswm.info/water-nutrient-cycle/water-use/hardwares/optimisation-water-use-industries/reuse-water-betweenbusinesses (accessed on 30 April 2021).

11. DG for Internal Market, Industry, Entrepreneurship and SMEs. Analysis of Certain Waste Streams and the Potential of Industrial Symbiosis to Promote Waste as a Resource for EU Industry; Publications Office of the European Union: Luxembourg, 2015. [CrossRef] 
12. Cioca, L.I.; Ivascu, L.; Rada, E.C.; Torretta, V.; Ionescu, G. Sustainable development and technological impact on CO2 reducing conditions in Romania. Sustainability 2015, 7, 1637-1650. [CrossRef]

13. Patel, J. 4-Step Wastewater Sludge Treatment Process. Water Online. 2019. Available online: https://www.wateronline.com/doc/ step-wastewater-sludge-treatment-process-0001 (accessed on 30 April 2021).

14. Dad, K.; Wahid, A.; Khan, A.A.; Anwar, A.; Ali, M.; Sarwar, N.; Ali, S.; Ahmad, A.; Ahmad, M.; Khan, K.A.; et al. Nutritional status of different biosolids and their impact on various growth parameters of wheat (Triticum aestivum L.). Saudi J. Biol. Sci. 2019, 26, 1423-1428. [CrossRef] [PubMed]

15. Collivignarelli, M.C.; Canato, M.; Abba, A.; Miino, M.C. Biosolids: What are the different types of reuse? J. Clean. Prod. 2019, 238, 117844:1-117844:21. [CrossRef]

16. National Authority Romanian Waters, Planul Naţional de Management Actualizat Aferent Porţiunii din Bazinul Hidrografic Internaţional al Fluviului Dunărea Care este Cuprinsă în Teritoriul României. Sinteza Planurilor de Management Actualizate la nivel de bazine/spaţii hidrografice, The Updated National Management Plan for the Portion of the International River Basin of the Danube River Which is Included in the Territory of Romania. Synthesis of the Updated Management Plans at the Level of Basins/Hydrographic Spaces. 2016. Available online: www.rowater.ro (accessed on 30 May 2021).

17. Ministry of Environment and Forests; National Authority Romanian Waters. Situaţia în România a Apelor Uzate Urbane şi a Nămolului Provenit din Staţiile de Epurare-Broşură Pentru Public/Situation in Romania of Urban Wastewater and Sludge from Sewage Treatment Plants-Brochure for the Public. 2012. Available online: www.rowater.ro (accessed on 30 May 2021).

18. National Statistics Institute. Tempo Database Data. 2020. Available online: https:/ /insse.ro/cms / (accessed on 30 June 2021).

19. National Agency for Environment Protection. Raport Anual Privind Starea Mediului în România, Anul 2018, Annual Report on the State of the Environment in Romania, Year 2018, Bucureşti, Romania. 2019. Available online: http://www.anpm.ro/ro/ raport-de-mediu (accessed on 30 May 2021).

20. Batali, L.; Carastoian, A. Caracterizarea, din punct de vedere geotehnic, a namolurilor de la statiile de epurare, in vederea depozitarii lor, Characterization, from a geotechnical point of view, of the sludge from the treatment plants, in the view of their storage. Rev. Constr. 2015, 117, 56-59.

21. Collivignarelli, M.C.; Abbà, A.; Miino, M.C.; Torretta, V. What Advanced Treatments Can Be Used to Minimize the Production of Sewage Sludge in WWTPs? Appl. Sci. 2019, 9, 2650. [CrossRef]

22. AM POS Mediu. Strategia Națională de Gestionare a Nămolurilor de Epurare_Partea a III-a, The National Sewage Sludge Management Strategy_Part III; Directia Generala AM POS Mediu: Bucuresti, Romania, 2012.

23. Hall, J. Ecological and Economical Balance for Sludge Management Options. 2006. Available online: Ec.europa.eu (accessed on 30 June 2021).

24. EPA, Basic Information about Biosolids. United States Environmental Protection Agency. 2019. Available online: https: //www.epa.gov/biosolids/basic-information-about-biosolids (accessed on 28 February 2021).

25. Al-Gheethi, A.A.; Efaq, A.N.; Bala, J.D.; Norli, I.; Abdel-Monem, M.O.; Kadir, M.O.A. Removal of pathogenic bacteria from sewage-treated effluent and biosolids for agricultural purposes. Appl. Water Sci. 2018, 8, 74:1-74:25. [CrossRef]

26. Ministry Order No. 344/2004 for the Approval of the Technical Norms on the Protection of the Environment and Especially of the Soils, When the Sewage Sludges Are Used in Agriculture; Monitorul Oficial al României: Bucuresti, Romania, 2004.

27. Aquaserv Târgu-Mureş, Utilizarea nămolului de Epurare în Agricultură, Broşură, Use of Sewage Sludge in Agriculture, Brochure. 2016. Available online: www.aquaserv.ro (accessed on 30 April 2021).

28. Kitchenham, B. Procedures for Performing Systematic Reviews; 33(TR/SE-0401); Keele University: Keele, UK, 2004.

29. Chojnacka, K.; Moustakas, K.; Witek-Krowiak, A. Bio-based fertilizers: A practical approach towards circular economy. Bioresour. Technol. 2020, 295, 122223. [CrossRef] [PubMed]

30. Collivignarelli, M.C.; Abbà, A.; Frattarola, A.; Miino, M.C.; Padovani, S.; Katsoyiannis, I.; Torretta, V. Legislation for the reuse of biosolids on agricultural land in Europe: Overview. Sustainability 2019, 11, 6015. [CrossRef]

31. Milieu Ltd.; WRc; RPA. Environmental, Economic and Social Impacts of the use of Sewage Sludge on Land-Final Report -Part III: Project Interim Reports. 2008. Available online: https:/ / ec.europa.eu/environment/archives/waste/sludge/pdf/part_iii_ report.pdf (accessed on 30 May 2021).

32. Borjesson, G.; Katterer, T. Soil fertility effects of repeated application of sewage sludge in two 30-year-old field experiments. Nutr. Cycl. Agroecosyst. 2018, 112, 369-385. [CrossRef]

33. Melo, W.; Delarica, D.; Guedes, A.; Lavezzo, L.; Donha, R.; de Araujo, A.; de Melo, G.; Macedo, F. Ten years of application of sewage sludge on tropical soil. A balance sheet on agricultural crops and environmental quality. Sci. Total Environ. 2018, 643, 1493-1501. [CrossRef] [PubMed]

34. Eid, E.M.; Alrumman, S.A.; El-Bebany, A.F.; Fawy, K.F.; Taher, M.A.; Hesham, A.E.; El-Shaboury, G.A.; Ahmed, M.T. The evaluation of sewage sludge application as a fertilizer for broad bean (Faba sativa Bernh.) crops. Food Energy Secur. 2018, 7, e00142. [CrossRef]

35. Broderick, S.R.; Evans, W.B. Biosolids Promote Similar Plant Growth and Quality Responses as Conventional and Slow-release Fertilizers. Horttechnology 2017, 27, 794-804. [CrossRef]

36. De Abreu, A.H.M.; Leles, P.S.D.; Alonso, J.M.; Abel, E.L.D.; de Oliveira, R.R. Characterization of sewage sludge generated in Rio de Janeiro, Brazil, and perspectives for agricultural recycling. Semin. Cienc. Agrar. 2017, 38, 2433-2447. [CrossRef] 
37. Da Paixao, J.L.; Gabrielli, G.; Coraucci, B.; Tonetti, A.L. Use of stabilization pond sludge in cultivation of roses. Rev. Bras. Eng. Agric. Ambient. 2014, 18, 85-89. [CrossRef]

38. Franco, A.; Abreu, C.H.; Perecin, D.; Oliveira, F.C.; Granja, A.C.R.; Braga, V.S. Sewage sludge as nitrogen and phosphorus source for cane-plant and first ratoon crops. Rev. Bras. Cienc. Solo 2010, 34, 553-561. [CrossRef]

39. Bittencourt, S.; Serrat, B.M.; Aisse, M.M.; Gomes, D. Sewage sludge usage in agriculture: A case study of its destination in the Curitiba Metropolitan Region, Paraná, Brazil. Water Air Soil Pollut. 2014, 225, 2074:1-2074:8. [CrossRef]

40. Severn Trent Water. Biosolids Recycling. Available online: https://www.stwater.co.uk/about-us/environment/biosolidsrecycling/ (accessed on 30 March 2021).

41. Law 384/2013 on the Approval of the Government Emergency Ordinance (GEO) 31/2013 for the Amendment and Completion of GEO 196/2005 on the Environment Fund; Monitorul Oficial al României: Bucuresti, Romania, 2013.

42. Emergency Ordinance 48/2017, Which Amends and Supplements the GEO 196/2005 on the Environment Fund; Monitorul Oficial al României: Bucuresti, Romania, 2017.

43. Ionescu, C.A.; Coman, M.D.; Moiceanu Marin, E.L.; Paschia, L.; Gudanescu Nicolau, N.L.; Cucui, G.; Stanescu, S.G. The Analysis of the Economic Effects on the Greening and Recovery of the Sludge Waste Resulting from the Biogas Production Activity. Sustainability 2019, 11, 4922. [CrossRef]

44. Sigua, G.; Adjei, M.; Rechcigl, J. Cumulative and residual effects of repeated sewage sludge applications: Forage productivity and soil quality implications in South Florida, USA. Environ. Sci. Pollut. Res. 2005, 12, 80-88. [CrossRef] [PubMed]

45. Morosini, C.; Marsoni, M.; Torretta, V.; Conti, F.; Ragazzi, M.; Rada, E.C.; Cioca, G. Factors Affecting Spatial and Temporal Concentration Variability of Pharmaceuticals: Comparison between Two WWTPs. Sustainability 2017, 9, 1466. [CrossRef]

46. Semblante, G.U.; Hai, F.I.; Huang, X.; Ball, A.S.; Price, W.E.; Nghiem, L.D. Trace organic contaminants in biosolids: Impact of conventional wastewater and sludge processing technologies and emerging alternatives. J. Hazard. Mater. 2015, $300,1-17$. [CrossRef] [PubMed]

47. Eurostat, Agriculture-Greenhouse Gas Emission Statistics. 2017. Available online: https://ec.europa.eu/eurostat/statisticsexplained/index.php?title=Archive:Agri-environmental_indicator_-_greenhouse_gas_emissions (accessed on 30 March 2021).

48. Glab, L.; Sowinski, J. Sustainable Production of Sweet Sorghum as a Bioenergy Crop Using Biosolids Taking into Account Greenhouse Gas Emissions. Sustainability 2019, 11, 3033. [CrossRef]

49. Lindsay, B.E.; Zhou, H.J.; Halstead, J.M. Factors influencing resident attitudes regarding the land application of biosolids. Am. J. Altern. Agric. 2000, 15, 88-95. [CrossRef] 